\title{
VLADIMIR KOZÁK: AS AMIZADES DE UM LOBO SOLITÁRIO
}

\author{
Rosalice Carriel Benetti ${ }^{1}$
}

- Enviado em 29/08/2015

- Aprovado em 10/09/2015

\section{RESUMO}

Vladimir Kozák é um imigrante tcheco que veio para o Brasil em 1924. Trata-se de um nome significativo para estudiosos dos indígenas brasileiros. No entanto, sua trajetória como pesquisador é praticamente desconhecida no país e pouco se sabe sobre sua vida pessoal, suas relações de amizade, seus desejos e interesses. Qualificá-lo como engenheiro, fotógrafo, cineasta, artista ou mesmo etnólogo é pouco esclarecedor, pois era uma figura multifacetada que sempre esteve envolvida simultaneamente em diversas atividades. Esta pesquisa apoia-se, no estudo do seu arquivo pessoal, com ênfase na documentação epistolar. Analisamos a prática epistolar de Vladimir Kozák buscando interpretar as redes de amizade e os sentimentos que uniram essas pessoas. A amizade é observada como uma relação humana capaz de romper distâncias e ampliar horizontes, consolidando um espaço de conversação franca e de troca cultural e pessoal. Observamos as cartas como forma íntima de comunicação que possibilitam a exposição de ideias e trocas de experiência entre os correspondentes e amigos, que permite pensar as relações de amizade como formas de sentir e de agir que aproximam homens e mulheres.

Palavras-chave: Vladimir Kozák. Amizade. Imigrante. Cartas. Sentimentos.

\section{INTRODUÇÃO}

Procurando os amigos, percorro seus escritos. Anne Vincent-Buffault

Há uma infinidade de palavras que apontam para o significado do que seja a amizade: afeição, simpatia, confiança, fidelidade, lealdade, estima, ternura, paciência, respeito, tolerância ou aceitação entre outras. Os filósofos gregos utilizavam o termo Philia, geralmente traduzido como

\footnotetext{
${ }^{1}$ Graduada em Direito e História, especialista em Direito Penal e Criminologia (UFPR) e Sociologia Política (UFPR), especialista em História Social da Arte (PUCPR - 2012) e mestre em História pela Universidade Federal do Paraná (2015). Pesquisadora do grupo Oficina do Poder Judiciário do Paraná: Catalogação de Processos Crimes e Cíveis no Arquivo Público do Paraná. No Museu Paranaense atuou como estagiária no Setor de Antropologia, onde pesquisou e organizou a correspondência pessoal de Vladimir Kozák. Tem experiência na área de Direito em Segurança Pública onde atuou até 2005 e atualmente é voluntária no Museu Paranaense. Endereço eletrônico: iceb@brturbo.com.br.
} 
amizade, como fundamental para as relações sociais. Aristóteles ${ }^{2}$ considerava a amizade essencial à ética, e somente as pessoas boas e virtuosas estariam aptas a vivenciar uma amizade plena. Montaigne discutia a amizade a partir das ideias de Aristóteles, percebendo-a como "o mais alto ponto de perfeição na sociedade." 3

A antropóloga Claudia Rezende define a amizade como "uma relação pautada na sociabilidade" , fundamentada na afinidade, confiança e no "ato de compartilhar questões pessoais e íntimas." A autora explica que "a sociabilidade costuma estar mais presente nos momentos iniciais da amizade, enquanto a confiança e as revelações pessoais caracterizam uma maior solidificação da relação entre amigos."

Parece ser atemporal a busca de amizade pelo ser humano, que jamais é desprovida de sentido porque está sempre associada à concepção de partilhar. Faz parte da essência humana, que desde a infância procura alguém com quem possa dividir emoções e ideias, felicidades e infelicidades, confiança e apoio. A amizade é um componente significativo na vida de qualquer pessoa, é um espaço social que possibilita a criação de vínculos sociais e emocionais e que se caracteriza, especialmente, pela livre escolha e afeição pessoal. ${ }^{7}$ Trata-se de uma relação humana que apresenta características particulares; é capaz de romper distâncias e ampliar horizontes, consolidando um espaço de conversação franca e de troca cultural e pessoal.

Amizade é um laço que se constrói fundado em um vínculo interpessoal afetivo envolvendo um "processo de negociação constante sem regras pré-determinadas". ${ }^{8}$ É absolutamente inviável buscar enquadrar o amigo em um padrão específico, como tempo de conhecimento ou relação familiar ou alguém que tenha os mesmos gostos. A amizade refere-se a um espaço particular de confiança e confidência, compartilhamento de interesses, troca de ideias, pensamentos e palavras, numa relação livre de obrigações.

2 DURANT, WILL. Aristóteles e a ciência grega. In: A história da filosofia. São Paulo: Editora Nova Cultural, 1996.

${ }^{3}$ MONTAIGNE, Michel de. Ensaios I. São Paulo: Editora Nova Cultural, 1996. p. 178.

${ }^{4}$ REZENDE, Claudia Barcellos. Os significados da amizade: duas visões de pessoa e sociedade. Rio de Janeiro: Editora FGV, 2002. p. 145.

${ }^{5} I d$.

${ }^{6}$ Ibid., p. 146.

${ }^{7}$ ORTEGA, Francisco. Genealogias da amizade. São Paulo: Editora Iluminuras, 2002.

${ }^{8}$ ORTEGA, p.19. 
O personagem do amigo desempenha um papel relevante na vida dos indivíduos, contribuindo para o desenvolvimento social, emocional e cognitivo das pessoas. ${ }^{9}$ No caso de Vladimir Kozák ${ }^{10}$ um imigrante tcheco, que veio para o Brasil em busca da realização de seus sonhos e de novas oportunidades de trabalho, que manteve um reduzido círculo de amigos e foi apelidado de "lobo solitário", laços de amizade foram preservados pelo exercício da escrita. Através da troca epistolar, Kozák criou uma rede de relações pessoais, dialogou, mantendo laços intelectuais e afetivos.

\section{A TRAJETÓRIA DO PERSONAGEM}

Descrever esse homem é uma tarefa complexa, enquadrá-lo como engenheiro é limitar sua atuação; assim como indicá-lo fotógrafo, cineasta, artista ou mesmo etnólogo é arriscado e pouco esclarecedor, pois estamos nos referindo a uma figura multifacetada que sempre esteve envolvida simultaneamente em inúmeras atividades. O seu envolvimento com pintura e fotografia antecedem sua vinda para o Brasil, pois desde muito jovem quando ainda vivia na atual República Tcheca, buscou conhecer e estudar essas artes.

Vladimir Kozák nasceu em 19 de abril de 1897, em Bystrice ped Hestýmem, zona rural da Morávia, antigo Império Austro-Húngaro, ${ }^{11}$ filho de František e Adolfina Kozák. A família,

\footnotetext{
${ }^{9}$ SOUZA, Luciane Karine de Souza; HUTZ, Claudia Simon. Relacionamentos pessoais e sociais: amizade em adultos. Psicologia em Estudo, Maringá, v. 13, n. 2, p. 257-265, abr./jun. 2008. Disponível em: <http://www.scielo.br/scielo.php?script=sci_arttext\&pid=S1413-73722008000200008>. Acesso em: 26/8/1014.

${ }^{10}$ Vladimir Kozák (1897, Bystrice ped Hestýmem, Morávia - 1989, Curitiba, Paraná).

${ }^{11}$ Em 1897, quando Kozák nasceu, a Morávia fazia parte do Império Austro-Húngaro. Com o fim da Primeira Guerra Mundial e a derrota austro-húngara, tchecos e eslovacos se uniram para formar a Tchecoeslováquia em 1918, com Praga tornando-se a capital. O Estado foi constituído a partir da combinação da Boêmia, Morávia, Silésia, Eslováquia e a Rutênia. Entre os anos de 1918 e 1935, foi Presidente da República Tomás Garrique Masaryk. Entre 1920 e 1930 a República Tcheca figurou entre os dez países mais desenvolvidos do mundo, com uma indústria muito avançada. Prosperidade e democracia que terminaram com a agressão da Alemanha de Hitler. A conferência de Munique determinou a entrega da região dos Sudetos a Alemanha e a subsequente ocupação alemã da Boêmia e Morávia. Em março de 1939, ocorreu a anexação de toda a Tchecoeslováquia por Hitler e imposição de um regime de repressão que pos fim à existência do Estado tcheco independente. Nos anos 1945 a 1948, Edvard Beneš foi o Presidente da Tchecoeslováquia. Entre 1948 e 1989 Tchecoeslováquia esteve sob regime totalitário. Em 1990, foi eleito presidente o dissidente e escritor Václav Havel. E, em 1993, com a divisão da Tchecoeslováquia, foi criada a República Tcheca. República Tcheca. Disponível em: <http://www.czechtrade.com.br/sobre-a-republica-tcheca/historia/>. Acesso em: 20/11/2014; República Tcheca. Disponível em: http://www.mzv.cz/brasilia/pt/informac_es_sobre_a_republica_tcheca/historia/index.html>. Acesso em: 20/11/2014;
} 
constituída dos pais e uma irmã, Karla Kozák, ${ }^{12}$ um ano mais velha, vivia da produção no campo e do trabalho mais especializado de seus pais. O pai mantinha uma oficina "de serralheiro mecânico,"13 onde produzia instrumentos de precisão, enquanto a mãe, além de cuidar da casa, fazia bordados regionais.

Ele iniciou seus estudos na vila de origem, estudou engenharia mecânica na Escola Nacional Tcheca de Ensino Industrial de Brno, ${ }^{14}$ Morávia e, ao mesmo tempo escultura e pintura com o professor Jan Kolár, da Purkyne University, no Departamento de Arquitetura, pois desde a infância demonstrou interesse pelo desenho.

Ele tinha 17 anos quando eclodiu a Primeira Guerra Mundial e incorporou-se ao exército, servindo no Regimento de Aviação, ${ }^{15}$ onde trabalhou como apparat-chauffeur de aviões na Bulgária e Itália. Neste ambiente é possível constatar que ele não somente observou, como também vivenciou grandes transformações na Europa como a decadência do Império Austro-Húngaro, a Primeira Guerra Mundial e a independência da Tchecoeslováquia.

Kozák é filho do Império Austro-Húngaro, um importante Estado europeu, que resultou de um compromisso entre as nobrezas austríaca e húngara em 1867, formando uma monarquia dualista. ${ }^{16} \mathrm{O}$ imenso Império abrigou diferentes grupos étnicos e nacionalidades ${ }^{17}$ constituindo-se em um verdadeiro mosaico étnico, possibilitando o contato com diferentes grupos linguísticos, o

OLIVEIRA, José Renato Gomes de. Coronel Redl e o Império Austro-Húngaro: ascensão e decadência do Antigo Regime e as motivações da I Guerra Mundial. Revista O olho da história, Salvador: UFBA, n. 11, 2008. Disponível em: <http://oolhodahistoria.org/n11/textos/joserenato.pdf>. Acesso em: 20/11/2014.

${ }^{12}$ Karla Kozáková ou Karla Kozák (Bystrice pod Hostýnem, 1896 - Curitiba, 1960).

13 TREVISAN, Edilberto. Vladimir Kozák (1897-1979), "O Braide Pemegare" dos Bororo. In: Boletim do Instituto Histórico, Geográfico e Etnográfico Paranaense. Curitiba, 1979. v. 36, p. 10.

${ }^{14}$ Capital da Morávia.

15 Incorporado ao exército no período compreendido entre 8 fev. 1916 e 28 out. 1918, Kozák participou de exercício de mobilização em novembro de 1921. CARTEIRA MILITAR de Vladimir Kozák. Museu Paranaense/SEEC-PR. Original em tcheco, tradução de Martina Cermakova.

${ }^{16}$ A monarquia dualista do Império Austro-Húngaro apresentou-se como dois Estados iguais, com capitais e sistemas políticos próprios, mas com elementos em comum, como a figura do imperador e os ministérios da Marinha, Finanças, Guerra e Negócios Estrangeiros. OLIVEIRA. Op cit.

${ }^{17}$ Tchecos, eslovacos, ucranianos, poloneses, eslovenos, sérvios, romenos, croatas, entre outros. 
que, presumivelmente, facilitou o conhecimento de Kozák pelas línguas tcheca e alemã, bem como estimulou-o a estudar inglês e esperanto. ${ }^{18}$

Quando ele estava com 21 anos, em 1918, foi proclamada a independência da Tchecoeslováquia que, apesar das diferenças culturais, linguísticas e religiosas, uniu os tchecos e os eslovacos. O período compreendido entre 1918 e 1938, denominado de Primeira República Tchecoeslovaca, o novo Estado, concebido como democracia parlamentar, caracterizou-se pela estabilidade política e pelo desenvolvimento econômico. Mas, apesar desse ambiente geral, em 1924, Kozák optou por transferir-se para o Brasil.

Desejo de conhecer novos lugares e (ou) ímpeto da juventude? Não são claros os motivos que influenciaram a sua escolha de emigrar. Muitos são os fatores que podem ter contribuído para isso: leitura, curiosidade, oportunidade ou quem sabe, provavelmente, a soma destes fatores. Quando jovem, ele foi um leitor voraz e assíduo das aventuras e viagens fantásticas do escritor alemão Karl Friedrich May ${ }^{19}$ e do personagem Tarzan, do escritor norte-americano Edgar Rice Burroughs,${ }^{20}$ leituras retomadas quando ficou mais idoso e estava impossibilitado de viajar.

Não resta dúvida que o conteúdo dos livros do escritor alemão Karl May estimulou a fantasia de toda uma geração na Europa e na Alemanha, despertando o desejo de emigração para a exótica e ainda inexplorada América Latina. Para o professor de história, Stefan Rinke, "a tomada ficcional de um continente estranho era fundamentada em um pensamento político mundial, que condizia com o espírito imperialista daquela época e legitimava a busca alemã de um 'lugar ao sol'."21

Mas, outros fatores também devem ter pesado na opção de Kozák em buscar a América Latina para viver, como a observação de selos estranhos que frequentemente surgiam em casa

\footnotetext{
${ }^{18}$ Esperanto é uma língua criada pelo médico polonês, Dr. Lázaro Zamenhof, em 1887, com o objetivo de facilitar a comunicação no mundo.

${ }^{19}$ Escritor alemão de livros de viagens e aventuras em paisagens distantes no Oriente, América do Norte e América do Sul.

${ }^{20}$ No acervo de Kozák no Museu Paranaense, entre os livros, há uma coleção das histórias de Tarzan.

${ }^{21}$ RINKE, Stefan. O continente ainda inexplorado: a República Federal Alemã na era Adenauer e a América Latina em contexto global. In: Revista História Unisinos, São Leopoldo, RS, v.17, n. 2, p. 73, 2013. Disponível em: < http://revistas.unisinos.br/index.php/historia/issue/view/408>. Acesso em 30.10.2014.
} 
quando criança, pois o pai correspondia-se com um parente, possivelmente um avô ${ }^{22}$, que morava no Rio Grande do Sul. ${ }^{23}$

De qualquer modo, com 27 anos de idade, após ter vivido em Bystrice pod Hostyn, Brno e Viena, ele emigrou para o Brasil em busca da realização de seus sonhos e de novas oportunidades de trabalho. Em 1924, chegou ao Brasil e se estabeleceu em Vitória, Espírito Santo, onde contatos anteriores haviam garantido um emprego que não se efetivou. Houve uma tentativa de constituir uma empresa que consertava e produzia peças para uma fábrica de tecidos que não deu certo. Finalmente surgiu um emprego e ele foi contratado como engenheiro da empresa Electric Bond and Share Company, com sede em Nova Iorque, trabalhando no Espírito Santo. Mais tarde ele mudouse para Minas Gerais ${ }^{24}$ e depois Bahia. ${ }^{25}$

Em 1938, ele instalou-se em Curitiba, trabalhando como engenheiro mecânico da Companhia Força e Luz do Paraná, no cargo de Superintendente de Energia. No ano seguinte, em virtude da morte dos pais, Karla Kozák, ${ }^{26}$ veio para Curitiba, passando a residir com o irmão. "Ela estava acompanhando os pais idosos. Quando eles faleceram ela resolveu vir. O que para ele foi uma felicidade." 27

Nessa ocasião Karla assumiu o compromisso de se ocupar dos afazeres domésticos, além de acompanhá-lo em viagens ao interior do país e auxiliá-lo nas expedições e nas filmagens. $\mathrm{Na}$ Tchecoeslováquia, ela tinha frequentado a escola profissional de bordado e era professora, formada pela Escola de Artes Aplicadas de Praga (1926-1929). ${ }^{28}$ No Brasil, ela pintou muitas aquarelas, a maioria de flores, que fazem parte do acervo de Vladimir Kozák.

\footnotetext{
${ }^{22}$ FAULHAMER, František. Carta para Vladimir Kozák. Bratislava, 07 mar. 1966. 2 f. Museu Paranaense/SEECPR. Original em tcheco, tradução Martina Cermakova.

23 TREVISAN. Edilberto. Vladimir Kozák (1897-1979), “O Braide Pemegare” dos Bororo. In: Boletim do Instituto Histórico, Geográfico e Etnográfico Paranaense. Curitiba, v. 36, 1979, p. 10.

${ }^{24}$ Gerente do Setor Técnico da Companhia Força e Luz de Minas Gerais.

${ }^{25}$ Engenheiro Chefe da Companhia Mista Circular de Carris da Bahia.

${ }^{26}$ Karla mudou-se para o Brasil em 1939 e em 1954, obteve cidadania brasileira. Foi companheira e amiga do irmão, participando de diversas excursões pelo Brasil a grupos indígenas. Faleceu em 1960, em decorrência de complicações de malária, fato que repercutiu negativamente em Vladimir Kozák que, possivelmente, se culpou pelo ocorrido.

${ }^{27}$ BLASI. Oldemar. Entrevista sobre Vladimir Kozák. Curitiba, 05 maio 2013. Entrevista concedida a Rosalice Carriel Benetti e a antropóloga Fernanda Campelo Maranhão.

${ }^{28}$ HISTÓRICO Escolar da Escola de Artes Aplicadas de Praga. Museu Paranaense/SEEC-PR. Original em tcheco, tradução Martina Cermakova.
} 
Kozák trabalhou na Copel até se aposentar, quando então passou a dedicar o seu tempo, integralmente, ao Museu Paranaense e à Universidade do Paraná. Segundo o arqueólogo e exdiretor do Museu Paranaense, Oldemar Blasi, o engenheiro "foi considerado um dos maiores técnicos" da Força e Luz, fazendo "coisas fantásticas"29. Perfeccionista, exigente, criativo e dedicado, é interessante observar o método adotado por ele para localizar as pessoas que se utilizavam de um ardil para não pagar a conta da luz, e estariam furtando energia elétrica. Algo elementar, mas somente viável na Curitiba dos anos 40 e 50. Ele simplesmente passou a verificar, pessoalmente, as casas que mantinham a luz acesa à noite e comparar com o consumo registrado na conta.

E como o preço, ficou muito caro. Então começou a, divulgação, disseminação do "gato."30 A pessoa mexia no contador. Punham um cabo lá. Então o consumo aumentou e a renda diminuiu porque as pessoas não pagavam. O que ele fez? Ele saiu diversas vezes entre 6:00 horas e 7:00 horas da noite, rua por rua para ver se tinha lâmpada acesa e tudo. Ora, se a casa tinha lâmpada acesa a noite toda e não gastava tanto. Então havia um "gato". Então ele começou a procura dos "gatos". ${ }^{31}$

Ainda que estivesse envolvido com sua atividade profissional na Força e Luz, Kozák não perdeu seu entusiasmo inicial com o registro de paisagens e da natureza do Brasil, prosseguiu fotografando, desenhando e pintando no tempo livre. Possivelmente, foi a paixão pela fotografia ${ }^{32}$ que fez com que se unisse a um grupo de pessoas interessadas na natureza, dispostas a excursionar pela periferia de Curitiba, Rio Branco do Sul, Serra do Mar, litoral e algumas grutas, em longas caminhadas a locais de difícil acesso, mas que resultavam em produção de belas imagens. ${ }^{33}$

\footnotetext{
${ }^{29}$ BLASI, 2013.

${ }^{30}$ Gato é o nome dado à ligação clandestina, neste caso de energia elétrica, com a finalidade de furtar energia elétrica ou alterar a leitura do medidor.

${ }^{31}$ BLASI, 2013.

$32 \mathrm{O}$ interesse de Kozák pela fotografia e os procedimentos para obter imagens de qualidade são anteriores à sua chegada ao país. Em 1924, durante a viagem da Europa para o Brasil, ele já utilizava máquina fotográfica para registrar suas impressões, bem como possuía conhecimento na área, demonstrando preocupação com o registro de paisagens e as dificuldades para revelar o material. Entusiasmado com as possibilidades de fotografar a natureza local, foi difícil, para ele, compreender que as pessoas (os brasileiros) não estavam interessadas em registrar imagens que considerava tão surpreendentemente belas, até mesmo porque, conforme ele contou, na Europa precisava aguardar dias para que surgisse uma oportunidade que valesse a pena fotografar.
}

${ }^{33}$ Em 1943 Kozák estava filiado ao Foto Clube do Paraná. Os fotoclubes surgiram no Brasil a partir dos anos 30, caracterizando-se "pelo seu perfil elitista e pela busca de fazer da fotografia uma atividade artística." Em geral seus integrantes eram profissionais de condição financeira estável "que podiam dedicar-se a fotografia nas horas vagas." SILVA, Andressa Ignácio. Fotógrafos lambe-lambe e fotoclubista: análise de perfil e perspectiva social da produção fotográfica. In: ENCONTRO NACIONAL DE ESTUDOS DA IMAGEM, II, 2009, Londrina, Pr. Anais. Londrina, 
A descrição desses passeios indica muito do bom condicionamento físico de Kozák, que ao longo dos anos participou e organizou frequentes idas a campo ${ }^{34}$ em diferentes regiões do país que exigiam um bom preparo físico, disciplina e tenacidade. Entre as pessoas que faziam parte dessas aventuras nos arredores de Curitiba são mencionadas nas suas correspondências pessoais: o cônsul inglês Norman Rowe, o escultor e medalhista argentino José Peon ${ }^{35}$ e a canadense Marjory Bayllon. ${ }^{36}$ Um aspecto interessante passível de análise mais apurada que convém destacar, é que todas as pessoas indicadas que participavam dessas excursões não eram brasileiras, mas de outras nacionalidades, que encontraram nesta atividade um espaço de sociabilidade que os agregava.

Foi por intermédio destas pessoas, que Kozák conheceu e estabeleceu relações profissionais com José Loureiro Fernandes, ${ }^{37}$ na ocasião Diretor do Museu Paranaense que, em 1946, convidou-o para coordenar a Seção de Cinema da instituição, função que ele exerceu até 1963.

Empreendedor e disposto a inovar, Loureiro Fernandes ${ }^{38}$ havia assumido a direção do Museu em 1936 e dois anos após já havia reorganizado a instituição, reestruturando-a, contando com o apoio de colegas do Círculo de Estudos Bandeirantes e da recém-criada Faculdade de Filosofia, Ciências e Letras do Paraná. ${ }^{39}$

UEL, 2009. $\quad$ p. $1232-1239 . \quad$ Disponível em:

<www.uel.br/eventos/eneimagem/anais/trabalhos/pdf/SILVA_AndressaIgnacio> Acesso em: 17/3/2014.

${ }^{34}$ Detalhes das idas a campo e viagens de Kozák exigiriam um capítulo à parte, que está além dos objetivos deste artigo, mas que poderão ser explorados em outro trabalho.

35 José Peon foi escultor e medalhista argentino que veio para o Paraná em 1914. Teve uma prolífera produção nos anos de 1940. FERRARINI, Sebastião. Círculo de Estudos Bandeirantes Documentado. Curitiba: Editora Universitária Champagnat, 2011. p. 253.

${ }^{36}$ Marjory Brysson ou Marjory Doble Baillon manteve correspondência com Kozák entre os anos de 1940 à 1978. Descreve pelo menos três destas excursões no ano de 1940: Pico do Marumbi, Gruta das Fadas e Serra do Mar na cachoeira do rio Ipiranga.

${ }^{37}$ BLASI, 2013.

${ }^{38}$ O professor, médico, antropólogo e historiador português José Loureiro Ascenção Fernandes (1903-1977) foi uma "figura icônica da história do Paraná nos anos 1940." Pessoa de influência nos meios políticos e culturais, assumiu a direção do Museu Paranaense em 1936, inaugurando uma fase científica da instituição. Completamente inserido na sociedade local, teve participação ativa na política cultural e na política acadêmica paranaense. Atuou como Secretário de Estado da Cultura e Saúde Pública; Provedor da Santa Casa de Misericórdia; cumpriu mandato político de vereador. FURTADO, Maria Regina. José Loureiro Fernandes: o paranaense dos museus. Curitiba: Imprensa Oficial, 2006; ARDIGÓ, Fabiano. Uma ciência improvável: o Museu Paranaense entre 1940 e 1960. In: ARDIGÓ, Fabiano (org.). Histórias de uma ciência regional. São Paulo: Editora Contexto, 2011. p. 109.

${ }^{39}$ CECCON, Roseli Santos. Em busca de uma "arqueologia brasileira": Universidade do Paraná, décadas de 1950 a 1970. 171 f. Dissertação (Mestrado em História) - Faculdade de Filosofia e Ciências Humanas, Pontifícia Universidade Católica do Rio Grande do Sul, Porto Alegre, $2011 . \quad$ Disponível em: <http://repositorio.pucrs.br/dspace/handle/10923/3853>. Acesso em: 12/8/2013. 
A partir de 1946, Kozák "passou a documentar por meio de fotos e filmes cinematográficos" 40 as pesquisas que, anteriormente, "eram executadas pelos próprios excursionistas ou encomendadas a profissionais". ${ }^{41}$ No entanto, oficialmente Kozák ingressou no “corpo de assistência" do Museu em 1947, como chefe da "subsecção de cinema educativo", uma atividade de projeção no meio intelectual, mas não remunerada. ${ }^{42}$

Essa foi uma opção que gerou questionamentos de nossa parte, já que ele não era uma pessoa de posses, tratava-se de um estrangeiro que estava há poucos anos na cidade e dependia de seu trabalho para o sustento, portanto não poderia prescindir de uma remuneração. Mas, buscando compreender todos os interesses envolvidos, tanto o do diretor do Museu como o do engenheiro, indiscutivelmente, ficou evidenciado que ambos se beneficiavam reciprocamente desse pertencimento. $\mathrm{O}$ que esclarece por que apesar das dificuldades burocráticas, o diretor insistiu e trabalhou politicamente para efetivar o seu ingresso na instituição.

O interesse de Loureiro Fernandes em incluir Vladimir Kozák no corpo técnico era plenamente justificado em face do processo de reestruturação pelo qual o Museu Paranaense passava nos anos de 1940, inaugurando uma fase científica, cujos objetivos oscilavam "entre fins educacionais e interesses científicos". ${ }^{43}$ Em linhas gerais, durante este período houve uma intensificação de atividades e frequente contato com outras instituições científicas nacionais e internacionais $^{44}$ com a prática de intercâmbio cultural por meio de troca de correspondência, publicações e visitas de professores, pesquisadores de outros países e alunos universitários.

O principal objetivo da direção, segundo Fabiano Ardigó ${ }^{45}$, era apresentar uma pesquisa científica de qualidade com vistas a obter um título de excelência para o Museu. Entre os anos de

\footnotetext{
${ }^{40}$ CECCON, Roseli Santos. Em busca de uma "arqueologia brasileira”: Universidade do Paraná, décadas de 1950 a 1970. 171 f. Dissertação (Mestrado em História) - Faculdade de Filosofia e Ciências Humanas, Pontifícia Universidade Católica do Rio Grande do Sul, Porto Alegre, 2011. p.32. Disponível em: <http://repositorio.pucrs.br/dspace/handle/10923/3853>. Acesso em: 12/8/2013.

${ }^{41} I d$.

42 “A nomeação para os chefes de seções do Museu, caracterizava uma função honorária, considerada como nobre atitude de tão ilustres pioneiros [...]." FURTADO, Maria Regina. José Loureiro Fernandes: o paranaense dos museus. Curitiba: Imprensa Oficial. 2006. p. 73.

${ }^{43}$ ARDIGÓ. Op cit., p. 114.

${ }^{44}$ Atas e correspondências do Museu Paranaense. Museu Paranaense/SEEC-PR.

${ }^{45}$ ARDIGÓ. Op cit.
} 
1940 e $1960^{46}$, foram realizadas mais de sessenta expedições científicas, visando não só coletar espécimes, mas também de estudar a fauna e a flora do estado. Eram expedições que contavam com a participação de cientistas de outros centros de pesquisa, principalmente da Universidade de São Paulo e que precisavam ser registradas, por meio de fotografias ou filmes.

Em um cenário como esse, fica bem evidenciado que a presença de Vladimir Kozák foi significativa para o Museu; possibilitou a ampliação das ações e pesquisas desenvolvidas na instituição e atendeu aos interesses do diretor Loureiro Fernandes já que a utilização do filme e da fotografia era algo novo na Antropologia brasileira.

Até então o uso da fotografia e do filme na pesquisa antropológica brasileira, era considerado um método de documentação extremamente inovador no início da década de 1940, tendo sido utilizado de forma pioneira enquanto prática institucional pelo alemão Harald Schultz, ${ }^{47}$ assistente de Herbert Baldus, ${ }^{48}$ na Secção de Etnologia do Museu Paulista, entre 1944-1965.49

Além de conhecimento técnico sobre fotografia e filmagem, em muitas ocasiões Kozák utilizou equipamento de sua propriedade particular, para produzir material, ou seja, "documentação cinematográfica, de interesse cultural, sobre o Estado do Paraná," ${ }^{50}$ assim como custeou ou adiantou o pagamento de despesas que seriam de responsabilidade do Estado.

Mas, em que pese o esforço de Kozák para implementar os projetos do Museu, as relações com o diretor da instituição foram permeadas por divergências e conflitos. O engenheiro ocupava

\footnotetext{
${ }^{46}$ ARDIGÓ. Op cit., p. 133.

${ }^{47}$ Harald Schultz (1909-1966), fotógrafo e etnólogo, nasceu em Porto Alegre, filho de alemão com brasileira. Dos 6 aos 15 anos estudou na Alemanha e, na volta, apaixonou-se pela fotografia. Na capital federal trabalhou para o Serviço de Proteção ao Índio (SPI, atual Funai). Em 1947, Schultz deixou o SPI e foi trabalhar no Museu Paulista a convite de Herbert Baldus, professor alemão do curso de etnologia brasileira da Escola de Sociologia e Política de São Paulo. Embora não tivesse formação acadêmica, escreveu monografias e também recolheu material arqueológico para estudo. Seus artigos foram publicados em revistas no exterior e as fotos frequentaram as páginas da National Geographic.
}

${ }^{48}$ Herbert Baldus (1899-1970): etnólogo alemão, naturalizado brasileiro, que chegou ao país na década de 1920. Empreendeu pesquisas etnográficas entre vários grupos indígenas americanos, majoritariamente no Brasil. Participou do processo de institucionalização da Antropologia no Brasil nos anos 30. Ocupou a cadeira de Etnologia Brasileira na Escola Livre de Sociologia e Política de São Paulo (1939-1960), assumiu a chefia da Seção de Etnologia do Museu Paulista (1947-1968) e posteriormente diretor. PASSADOR, Luiz Henrique. Herbert Baldus e a antropologia no Brasil. Dissertação (Mestrado em Antropologia Social) - Instituto de Filosofia e Ciências Humanas, Universidade Estadual de Campinas. Campinas, $2002 . \quad$ Disponível em: <http://www.bibliotecadigital.unicamp.br/document/?code=vtls000241403>. Acesso em: 20/6/2013.

${ }^{49}$ MARANHÃO, Maria Fernanda Campelo. Vladimir Kozák e os índios do Brasil. Curitiba. Digitado.

${ }^{50}$ MUSEU PARANAENSE. Curitiba. Ofício Expedido no dia 25 jul. 1947. Correspondências de 1947. 
um lugar, claramente, definido de subordinado, pois o referencial naquele ambiente era Loureiro Fernandes. Kozák era o estrangeiro ocupando um lugar marginal, ou seja, um outsider. ${ }^{51}$

Apesar dessas dificuldades, os interesses institucionais sobrepujaram o relacionamento pessoal. E, em 1952, por influência e interesse pessoal de Loureiro Fernandes, que também era professor da Universidade, Kozák foi nomeado para a atividade remunerada de cinetécnico ${ }^{52}$ da Universidade do Paraná.

O emprego de engenheiro mecânico na Companhia Força e Luz do Paraná garantia a sua subsistência e possibilitava que Kozák dedicasse os finais de semana e as férias ao prazer de filmar e fotografar, produzindo documentários fotográficos e cinematográficos para o Museu e para a Universidade. Nas férias ele viajava pelo interior do país, por sua conta, registrando aspectos da natureza, das pessoas e do fazer do povo brasileiro, cujos filmes eram posteriormente, apresentados em escolas públicas e encontros culturais ${ }^{53}$. E, quando ele se aposentou na Força e Luz, ampliou sua participação, passando a dedicar parcela maior do seu tempo a ambas as instituições.

A paixão por registrar imagens do que viu, seja em desenho e pintura, seja em fotografia, foi uma constante na vida deste pesquisador, que, ao longo do tempo, ainda acrescentou o filme aos seus interesses, produzindo imagens únicas e surpreendentes sobre a cultura brasileira. Nos anos 50, Kozák viajou pelo país buscando registrar as paisagens e a cultura dos locais visitados; entre os anos de 1948 e 1966, realizou pelo menos vinte e três viagens de pesquisas a diversas aldeias indígenas pelo interior do Brasil.

Especial significado teve o seu trabalho de registrar a última etnia do Paraná. No período entre 1956 e 1961, Kozák esteve na Serra dos Dourados, ${ }^{54}$ noroeste do estado, onde filmou e fotografou os índios Xetá ${ }^{55}$ e aspectos de sua cultura, como preparo de alimentos, confecção de

\footnotetext{
${ }^{51}$ ELIAS, Norbert; SCOTSON, John L. Os estabelecidos e os outsiders: sociologia das relações de poder a partir de uma pequena comunidade. Rio de Janeiro: Jorge Zahar Ed., 2000.

${ }^{52}$ PARANÁ. Universidade do Paraná. Portaria n. ${ }^{0}$ 137, de 6 de fevereiro de 1952. Museu Paranaense/SEEC-PR.

${ }^{53}$ O relatório anual de 1949, de atividades da Seção de Cinema Educativo do Museu Paranaense, encaminhado por Kozák a Júlio Moreira, na ocasião Diretor do Museu, referiu-se à realização de "mais de 30 sessões cinematográficas," que ocorreram no Seminário Seráfico de Rio Negro, Santa Casa de Misericórdia de Curitiba e outros hospitais, colégios de Curitiba, Londrina e na Universidade do Paraná.
}

${ }^{54}$ A Serra dos Dourados localiza-se no município de Umuarama, Paraná.

${ }^{55}$ Os Xetá foram a última etnia do Estado do Paraná a entrar em contato com a sociedade nacional. Na década de 1940, frentes de colonização invadiram seu território, reduzindo-os drasticamente. No final dos anos 50, estavam praticamente exterminados. Em 1999 restavam apenas oito sobreviventes. Hoje, vivem dispersos nos estados do Paraná, Santa 
utensílios e rituais. “Até 1974, Kozák empreendeu cerca de 20 visitas aos Xetá, primeiro na floresta e mais tarde nas fazendas e nas cidades onde os poucos sobreviventes tinham se refugiado."56 Parcela desse material foi produzido para as pesquisas que estavam sendo desenvolvidas por Loureiro Fernandes desde 1955.

É importante destacar que Kozák realizou o seu desejo, percorreu um longo caminho pelo sertão, superou incontáveis adversidades humanas e naturais, descritas nas suas correspondências, com o objetivo de estudar diferentes culturas. Escreveu do seu modo a história, rituais e as tradições de diferentes povos, utilizando a linguagem da fotografia e do cinema. Ele foi perseverante e dedicado, fez um trabalho solitário, no qual parece que tomou como missão conhecer e dar a conhecer cada índio como único.

\section{O SIGNIFICADO DA AMIZADE}

O exercício da amizade resultou em rica e substanciosa correspondência trocada entre Kozák e pessoas de diferentes meios, de diversas partes do mundo: Tchecoeslováquia, Inglaterra, Estados Unidos, Canadá e Brasil entre outros. Analisando, atentamente, o conteúdo de seu conjunto documental é possível perceber que alguns desses correspondentes ultrapassaram a barreira da solidão e tiveram uma participação bem mais expressiva na vida dele, adquirindo o status de amizade.

"Ler uma carta é entrar em uma história sem conhecer a primeira palavra, sem saber o que aconteceu antes nem o que chegará depois, o que disse antes, nem o que se dirá depois." 57 O corresponder-se ocupou lugar especial nas suas relações, fundamentando vínculos de amizade; através das cartas ele prolongou a convivência amistosa e manteve um diálogo íntimo com algumas

Catarina e São Paulo. SILVA, Carmen Lúcia da. Povos Indígenas no Brasil: Xetá. 1999. Disponível em: < http://pib.socioambiental.org/pt/povo/xeta>. Acesso em: 7/2/2014.

${ }^{56}$ CARNEIRO, Robert. Introdução. In: Os índios Hetá: Peixe em Lagoa Seca. In: Boletim do Instituto Histórico, Geográfico e Etnográfico Paranaense. Curitiba, 1981. v. 38. p. 15.

${ }^{57}$ DAUPHIN, Cécile; POUBLAN, Danièle. Maneiras de escrever, maneiras de viver. In: BASTOS, M. H. C.; CUNHA, M. T. S.; MIGNOT, A. C. V. (orgs.). Destinos das letras: história, educação e escrita epistolar. Passo Fundo, RS: Editora UPF, 2002. p. 76. 
pessoas selecionadas, dividindo interesses, preocupações e sentimentos. Utilizando-se da escrita ele esteve trocando ideias e compartilhando muito de si e do outro.

O diálogo com Gene Woiski ${ }^{58}$, ilustradora e retratista, envolvia questões pessoais, como cuidados recíprocos com a saúde e troca de ideias acerca de técnicas de pintura e comentários sobre os temas de seus trabalhos.

Você que pinta, deve saber da alegria que a criação proporciona. Como você se sente feliz, quando você cria algo belo. Eu penso que Deus é beleza e nós nos esforçamos para chegar mais perto dele com o que nós criamos, mesmo que seja imperfeito e incompleto.

Não parei de sonhar. Os sonhos são muito preciosos. Talvez tenha ido ainda mais fundo; os belos ideais e aspirações da vida vêm até nós silenciosamente, suavemente, sem que a gente mesmo peça, assim como as verdadeiras amizades e o amor, o amor por tudo e por todos, o amor pela vida. ${ }^{59}$

Tecendo considerações sobre significado da amizade para ambos, Gene Woiski escreveu para Kozák: "É impossível retratar todos os subtítulos, as variações de nossos pensamentos e sentimentos - em palavras. É incompreensível as emoções que traz a felicidade de ter um amigo por perto. Amigo - uma palavra - mas que profundidade implica." ${ }^{60} \mathrm{Ou}$ ainda, "Oh, Kozák, é tão fácil reconhecer um amigo. É aquele que não ousa pedir-lhe nada mais material do que um tapinha gentil no ombro, ou uma palavra de coragem. Sinceremente, sou grata a você por isso."61

Atenta as características da personalidade de Kozák, e a dificuldade de fazer com que ele revelasse mais acerca de si, bem como contasse sobre eventuais problemas ou questões que o incomodavam, discutiu sobre a solidão dele, apelidando-o de "Lobo Solitário". ${ }^{2}$ Aliás, quando ambos já estavam idosos, ela criticou este comportamento do amigo: "Professor, como você

\footnotetext{
${ }^{58}$ Gene Woiski manteve uma correspondência regular com Kozák de 1967 a 1974. Ela foi ilustradora, retratista e decoradora. Casada com pintor e escultor João Woiski, o casal teve "importante atuação no meio cultural de Curitiba até a década de 1950, quando então transferem-se para São Paulo.” ARAUJO, Adalice M. de. Dicionário das Artes Plásticas no Paraná. Curitiba: Edição do Autor, 2006, v. 1, p. 57.
}

${ }^{59}$ WOISKI, Gene. Carta para Vladimir Kozák. São Paulo, 1º. mar. 1968. 2 f. Museu Paranaense/SEEC-Pr. Original em inglês, tradução nossa.

${ }^{60}$ WOISKI, Gene. Carta para Vladimir Kozák. São Paulo, 17 jun. 1969. 2 f. Museu Paranaense/SEEC-Pr. Original em inglês, tradução nossa.

${ }^{61}$ WOISKI, Gene. Carta para Vladimir Kozák. Amparo, 06 out. 1971. 2 f. Museu Paranaense/SEEC-Pr. Original em inglês, tradução nossa.

${ }^{62}$ Lone Wolf: WOISKY, Gene. Carta para Vladimir Kozák. São Paulo, 5 set. 1968. 3 f. Museu Paranaense/SEEC-PR. Original em inglês, tradução nossa. Carta para Vladimir Kozák. São Paulo, 09 jan. 1971. 1 f. Museu Paranaense/SEEC-PR. Original em inglês, tradução nossa; WOISKY, Gene. Carta para Vladimir Kozák. São Paulo, 14 dez. 1971. 2 f. Museu Paranaense/SEEC-PR. Original em inglês, tradução nossa; WOISKY, Gene. Carta para Vladimir Kozák. São Paulo, 16 dez. 1974. 1 f. Museu Paranaense/SEEC-PR. Original em inglês, tradução nossa. 
aprendeu a gostar da solidão? O que você faz com a vida, além de pintar, ler, comer (lavar os pratos) e dormir? Você ainda vai às suas viagens? Diga-me." 63

Ainda censurando a solidão do engenheiro, em dado momento ela ao mesmo tempo que questionou, carinhosamente ofereceu sua amizade, perguntando acerca do lugar ocupado pelas cartas nas suas relações, observando-as como um meio de preencher o vazio da solidão e um remédio para espantar a tristeza. "Não sinta-se sozinho, Kozák, aqui você tem alguém que está sempre pensando em você, que muitas vezes está ao seu lado com uma 'mão sobre seu ombro' de uma forma amigável quando você se sentir triste. Nossas cartas ajudam, não?" ${ }^{64}$ Em outra ocasião, a mesma amiga observou, "Você pode descansar no meu ombro amigo quando estiver com a cabeça cansada. Até o lobo solitário, que usualmente rosna, gosta de uma mão acariciando." 65

Entre os interlocutores de Kozák encontramos uma grande diversidade de pessoas: artistas, funcionários públicos, militares, pesquisadores interessados na questão indígena, empresas especializadas em filme e fotografia. A canadense Marjory Baillon não apresenta nenhuma característica específica, além da mais significativa que é a afinidade intelectual com seu correspondente e amigo. Assim, traduzir a relação havida entre eles torna-se um exercício de leitura de uma correspondência de aproximadamente quarenta anos, que envolve emoções e, concomitantemente, sinaliza e apaga respostas. Cada leitura e releitura apresentam novos indícios; trata-se de buscar a compreensão do que foi a prática da escrita para ambos.

O relacionamento entre eles foi muito particular, sendo a correspondência, fundamentalmente, a base e o elo desta amizade. Uma comprovação desta afirmativa foi o álbum de recortes e fotografias criado por Marjory, em determinado momento, ao qual ela dedicou atenção especial na organização e que denominou "álbum Kozák", cuja primeira referência é de $1949 .{ }^{66}$ No álbum eram colocadas fotos recebidas do amigo, bem como recortes de textos a ele relacionados.

Analisando atentamente esses comentários é possível perceber nela o desejo de interagir e de participar intimamente das atividades do engenheiro, uma maneira particular de tornar presente a

\footnotetext{
${ }^{63}$ WOISKI, Gene. Carta para Vladimir Kozák. São Paulo, 07. mar. 1975. 2 f. Museu Paranaense/SEEC-PR. Original em inglês, tradução nossa.

${ }^{64}$ WOISKI, Gene. Carta para Vladimir Kozák. São Paulo, 07. jan. 1969. 2 f. Museu Paranaense/SEEC-PR. Original em inglês, tradução nossa.

${ }^{65}$ WOISKI, Gene. Carta para Vladimir Kozák. São Paulo, 16 dez. 1974. 1 f. Museu Paranaense/SEEC-PR. Original em inglês, tradução nossa.
}

${ }^{66}$ BAILLON, Marjory. Carta para Vladimir Kozák. High Meadon Farm, Dunhan, Quebec, Canadá, 10 abr. 1950.2 f. Museu Paranaense/SEEC-PR. Original em inglês, tradução nossa. 
ausência do amigo. Ajuda a compor esse cenário os comentários dela sobre o destino das fotos que recebia dele. Por exemplo: "O álbum Kozák contém todas as fotos que você me enviou." ${ }^{67}$ Em diferentes momentos, ela revisava as imagens, tecendo comentários com os filhos e netos sobre as fotografias e as aventuras dele.

O álbum teve um valor expressivo para Marjory. Foi guardado como um bem muito precioso, um tesouro pessoal que serviria como legado para a velhice e para compartilhar com as pessoas que amava. Durante algumas de suas mudanças ela lamentou a permanência deste material no Canadá, avaliando-o como uma "maravilhosa" aquisição para a velhice que costumava rever. "Desafortunadamente a maioria de suas fotos (dois álbuns) ainda estão Canadá, então eu não posso olhar como eu gostaria de fazer para descobrir exatamente quais eram os Urubus." 68

Eu tenho e estava olhando para todas as suas fotos das Congadas. Eu tenho muitas delas e elas são maravilhosas. [...] Há muito tempo eu percebi que essas coisas foram passando, e devem ser capturadas agora... ou nunca.

Para minha velhice (se eu tiver uma) eu tenho grandes pacotes de suas cartas arrumadas - grandes aventuras dos primeiros dias - e dois álbuns de fotos. Eu olho para eles cada vez que vou para o Canadá. ${ }^{69}$ (Grifo nosso).

"Obrigado pelas fotografias... você e sete índios. Eu desejo que você envie mais delas. Meu álbum Kozák não está crescendo muito depressa, pense, eu ainda estou no volume 2." ${ }^{70}$ Em outro momento agradeceu as remessas de fotografias que relembravam o período em que sua família esteve residindo no Brasil: "obrigado pelas velhas fotos e o desenho do monjolo. Tony ${ }^{71}$ viu e lembrou-se da infância, fotos do Marumby [sic], eu nunca tinha visto estas fotos."72

\footnotetext{
${ }^{67}$ BAILLON, Marjory. Carta para Vladimir Kozák. High Meadon Farm, Dunhan, Quebec, Canadá, 18 fev. 1949.2 f. Museu Paranaense/SEEC-PR. Original em inglês, tradução nossa.

${ }^{68}$ BAILLON, Marjory. Carta para Vladimir Kozák. Craigmullen, Kircudbright, Escócia, 07 mar. 1965.5 f. Museu Paranaense/SEEC-PR. Original em inglês, tradução nossa.

${ }^{69}$ BAILLON, Marjory. Carta para Vladimir Kozák. Craigmullen, Kircudbright, Escócia, 18 jan. 1971.6 f. Museu Paranaense/SEEC-PR. Original em inglês, tradução nossa.

${ }^{70}$ BAILLON, Marjory. Carta para Vladimir Kozák. Montreal, Canadá, 12 fev. 195-. 4 f. Museu Paranaense/SEECPR. Original em inglês, tradução nossa.

${ }^{71}$ Anthony Baillon ou Tony é um dos dois filhos de Marjory.

72 BAILLON, Marjory. Carta para Vladimir Kozák. Craigmullen, Kircudbright, Escócia, 18 abr. 1972.3 f. Museu Paranaense/SEEC-PR. Original em inglês, tradução nossa.
} 
As informações de Marjory possibilitam compreender que ela efetivamente, não somente acompanhou a trajetória de Kozák, como também buscou compartilhar as experiências dele. Ela fez das fotos e das cartas um referencial para contar histórias de aventuras para os netos. "Eu tenho algumas belas fotos dos Xetá, tiradas por você... tantas velhas cartas de suas excursões aos selvagens estão a salvo no porão do Alex ${ }^{73}$ e eu olho para elas sempre que eu vou para casa, e mostro-as para o meu querido jovem neto Marc."74

Indiscutivelmente a relação entre eles extrapolou a tendência geral de uma ligação finita, que se acaba após a falta de proximidade e convívio; sobreviveu às várias mudanças, de cidade e de país, tornando-se uma relação duradoura. A presença física cotidiana da amiga tornou-se desnecessária, pois parece que eles estabeleceram um vínculo transcendente, permanente e contínuo, com as cartas ocupando um lugar diferenciado e essencial na vida dos dois. Nem o tempo, nem a distância foram obstáculos.

O tom entre eles se apresenta sempre afetuoso, com manifestações de apreço, mas também de críticas em algumas circunstâncias. Se a relação entre ambos, em algum momento, transitou no espaço pertencente ao "amor romântico," é difícil afirmar, visto que, apesar das afirmativas intimistas de Marjory, a amizade e seus desdobramentos está continuamente sendo reafirmada por eles nas cartas. Há um espaço de liberdade, autonomia e de cuidado de si entre eles, e ela tornou-se um suporte para "ouvir" acerca de questões profissionais e pessoais, mesmo que ele se apresentasse pouco comunicativo, conforme ela se queixou algumas vezes.

As cartas compartilham os modos de pensar e trazem à tona uma série de questões, que afetaram positivamente ou negativamente os amigos. Tiveram o significado de apoio para ouvir os problemas deles e, especialmente, possibilitar a presença de sentimentos de compreensão e a confiança mútua. Com frequência revelam episódios marcados de ressentimentos e mágoas, que geraram conflitos em cada um deles. O que eles conseguiram, efetivamente, é invejável pois, apesar da distância e das dificuldades de comunicação, mantiveram-se juntos, solidários, protegendo-se e ajudando-se. O diálogo deles esteve permeado de compartilhamento, confiança, apoio e fidelidade entre outros sentimentos.

Parece que o que o movia era o desejo contínuo de contato com os amigos com quem partilhava interesses e a rememoração do vivenciado em suas viagens. Sem dúvida as cartas

\footnotetext{
${ }^{73}$ Alex Baillon, filho de Marjory e pai do neto Marc.

${ }^{74}$ BAILLON, Marjory. Carta para Vladimir Kozák. Craigmullen, Kircudbright, Escócia, 24 jun. 1977. 2 f. Museu Paranaense/SEEC-PR. Original em inglês, tradução nossa.
} 
possibilitavam a sua atualização do que ocorria no mundo, além dos limites de onde vivia e uma permanente troca de ideias e conhecimento.

Segundo Dauphin e Poublan "a descoberta de uma carta incita sempre a contar: a história de sua descoberta, a história dos que escreveram, a história dos acontecimentos que evoca. $\mathrm{O}$ atrativo está no suspense, na decifração dos enigmas." ${ }^{75}$ Assim, conscientes do fascínio produzido pelas cartas, e como é instigante desvendar o seu conteúdo, buscamos observar a crítica do documento, apontada por Le Goff ${ }^{76}$ como o principal dever do historiador, e também refletir sobre o que Prochasson ${ }^{77}$ indica como "armadilhas" na utilização desta fonte.

Mas, este é tão somente um olhar sobre o conjunto documental, no qual optou-se por explorar a amizade, emoções e sentimentos na correspondência desse imigrante tcheco.

\section{REFERÊNCIAS}

ARAujo, Adalice M. de. Dicionário das Artes Plásticas no Paraná. Curitiba: Edição do Autor, 2006, v. 1.

BLASI. Oldemar. Entrevista sobre Vladimir Kozák. Curitiba, 05 maio 2013. Entrevista concedida a Rosalice Carriel Benetti e a antropóloga Fernanda Campelo Maranhão.

CARNEIRO, Robert. Introdução. In: Os índios Hetá: Peixe em Lagoa Seca. In: Boletim do Instituto Histórico, Geográfico e Etnográfico Paranaense. Curitiba, 1981. v. 38. p. 15.

CECCON, Roseli Santos. Em busca de uma "arqueologia brasileira": Universidade do Paraná, décadas de 1950 a 1970. 171 f. Dissertação (Mestrado em História) - Faculdade de Filosofia e Ciências Humanas, Pontifícia Universidade Católica do Rio Grande do Sul, Porto Alegre, 2011. Disponível em: <http://repositorio.pucrs.br/dspace/handle/10923/3853>. Acesso em: 12/8/2013.

DAUPHIN, Cécile; POUBLAN, Danièle. Maneiras de escrever, maneiras de viver. In: BASTOS, M. H. C.; CUNHA, M. T. S.; MIGNOT, A. C. V. (orgs.). Destinos das letras: história, educação e escrita epistolar. Passo Fundo, RS: Editora UPF, 2002. p. 75-87.

\footnotetext{
${ }^{75}$ DAUPHIN, Cécile; POUBLAN, p. 79.

${ }^{76}$ LE GOFF, Jacques. História e memória. Campinas (SP): Editora da UNICAMP, 2003. p. 575.

${ }^{77}$ PROCHASSON, Christophe. Atenção: verdade! Arquivos privados e renovação das práticas historiográficas. Revista Estudos Históricos. Rio de Janeiro, v. 11, n. 21, p. 105-120, 1998. Disponível em: <http://bibliotecadigital.fgv.br/ojs/index.php/reh/article/viewArticle/2064>. Acesso em: 20/5/2013
} 
DURANT, WILL. Aristóteles e a ciência grega. In: A história da filosofia. São Paulo: Editora Nova Cultural, 1996.

ELIAS, Norbert; SCOTSON, John L. Os estabelecidos e os outsiders: sociologia das relações de poder a partir de uma pequena comunidade. Rio de Janeiro: Jorge Zahar Ed., 2000.

FERRARINI, Sebastião. Círculo de Estudos Bandeirantes Documentado. Curitiba: Editora Universitária Champagnat, 2011.

FURTADO, Maria Regina. José Loureiro Fernandes: o paranaense dos museus. Curitiba: Imprensa Oficial. 2006.

LE GOFF, Jacques. História e memória. Campinas (SP): Editora da UNICAMP, 2003.

MARANHÃO, Maria Fernanda Campelo. Vladimir Kozák e os índios do Brasil. Curitiba. Digitado.

MONTAIGNE, Michel de. Ensaios I. São Paulo: Editora Nova Cultural, 1996.

OLIVEIRA, José Renato Gomes de. Coronel Redl e o Império Austro-Húngaro: ascensão e decadência do Antigo Regime e as motivações da I Guerra Mundial. Revista O olho da história, Salvador: UFBA, $\quad$ n. $11, \quad 2008 . \quad$ Disponível em: <http://oolhodahistoria.org/n11/textos/joserenato.pdf>. Acesso em: 20/11/2014.

ORTEGA, Francisco. Genealogias da amizade. São Paulo: Editora Iluminuras, 2002.

PASSADOR, Luiz Henrique. Herbert Baldus e a antropologia no Brasil. Dissertação (Mestrado em Antropologia Soial) - Instituto de Filosofia e Ciências Humanas, Universidade Estadual de Campinas. Campinas, 2002. Disponível em: <http://www.bibliotecadigital.unicamp.br/document/?code=vtls000241403>. Acesso em: 20/6/2013.

PROCHASSON, Christophe. Atenção: verdade! Arquivos privados e renovação das práticas historiográficas. Revista Estudos Históricos. Rio de Janeiro, v. 11, n. 21, p. 105-120, 1998. Disponível em: <http://bibliotecadigital.fgv.br/ojs/index.php/reh/article/viewArticle/2064>. Acesso em:

20/5/2013.

REZENDE, Claudia Barcellos. Os significados da amizade: duas visões de pessoa e sociedade. Rio de Janeiro: Editora FGV, 2002.

República Tcheca. Disponível em: <http://www.czechtrade.com.br/sobre-a-republicatcheca/historia/>. Acesso em: 20/11/2014.

República Tcheca. Disponível em: < http://www.mzv.cz/brasilia/pt/informac_es_sobre_a_republica_tcheca/historia/index.html >. Acesso em: $20 / 11 / 2014$.

RINKE, Stefan. O continente ainda inexplorado: a República Federal Alemã na era Adenauer e a América Latina em contexto global. In: Revista História Unisinos, São Leopoldo, RS, v.17, n. 2, 
p. 71-80, 2013. Disponível em: < http://revistas.unisinos.br/index.php/historia/issue/view/408>. Acesso em 30.10.2014.

SILVA, Andressa Ignácio. Fotógrafos lambe-lambe e fotoclubista: análise de perfil e perspectiva social da produção fotográfica. In: ENCONTRO NACIONAL DE ESTUDOS DA IMAGEM, II, 2009, Londrina, Pr. Anais. Londrina, UEL, 2009. p. 1232-1239. Disponível em: <www.uel.br/eventos/eneimagem/anais/trabalhos/pdf/SILVA_AndressaIgnacio>. Acesso em: $17 / 3 / 2014$

SILVA, Carmen Lúcia da. Povos Indígenas no Brasil: Xetá. 1999. Disponível em: < http://pib.socioambiental.org/pt/povo/xeta>. Acesso em: 7/2/2014.

SOUZA, Luciane Karine de Souza; HUTZ, Claudia Simon. Relacionamentos pessoais e sociais: amizade em adultos. Psicologia em Estudo, Maringá, v. 13, n. 2, p. 257-265, abr./jun. 2008. Disponível em: <http://www.scielo.br/scielo.php?script=sci_arttext\&pid=S141373722008000200008>. Acesso em: 26/8/1014.

TREVISAN, Edilberto. Vladimir Kozák (1897-1979), "O Braide Pemegare” dos Bororo. In: Boletim do Instituto Histórico, Geográfico e Etnográfico Paranaense. Curitiba, v. 36, p. 1-30, 1979.

\section{FONTES}

Atas e correspondências do Museu Paranaense. Museu Paranaense/SEEC-PR.

BAILLON, Marjory. Carta para Vladimir Kozák. High Meadon Farm, Dunhan, Quebec, Canadá, 18 fev. 1949. 2 f. Museu Paranaense/SEEC-PR. Original em inglês.

Carta para Vladimir Kozák. High Meadon Farm, Dunhan, Quebec, Canadá, 10 abr. 1950. 2 f. Museu Paranaense/SEEC-PR. Original em inglês.

. Carta para Vladimir Kozák. Montreal, Canadá, 12 fev. 195-. 4 f. Museu Paranaense/SEEC-PR. Original em inglês.

Carta para Vladimir Kozák. Craigmullen, Kircudbright, Escócia, 07 mar. 1965. 5 f. Museu Paranaense/SEEC-PR. Original em inglês.

Carta para Vladimir Kozák. Craigmullen, Kircudbright, Escócia, 18 jan. 1971. 6 f. Museu Paranaense/SEEC-PR. Original em inglês.

Carta para Vladimir Kozák. Craigmullen, Kircudbright, Escócia, 18 abr. 1972. 3 f. Museu Paranaense/SEEC-PR. Original em inglês.

Carta para Vladimir Kozák. Craigmullen, Kircudbright, Escócia, 24 jun. 1977. 2 f. Museu Paranaense/SEEC-PR. Original em inglês,

CARTEIRA MILITAR de Vladimir Kozák. Museu Paranaense/SEEC-PR. Original em tcheco. 
FAULHAMER, František. Carta para Vladimir Kozák. Bratislava, 07 mar. 1966. 2 f. Museu Paranaense/SEEC-PR. Original em tcheco..

HISTÓRICO Escolar da Escola de Artes Aplicadas de Praga. Museu Paranaense/SEEC-PR. Original em tcheco.

MUSEU PARANAENSE. Curitiba. Ofício Expedido no dia 25 jul. 1947. Correspondências de 1947.

PARANÁ. Universidade do Paraná. Portaria n. ${ }^{0}$ 137, de 6 de fevereiro de 1952. Museu Paranaense/SEEC-PR.

WOISKI, Gene. Carta para Vladimir Kozák. São Paulo, $1^{\circ}$. mar. 1968. 2 f. Museu Paranaense/SEEC-Pr. Original em inglês.

Carta para Vladimir Kozák. São Paulo, 5 set. 1968. 3 f. Museu Paranaense/SEEC-PR. Original em inglês.

Carta para Vladimir Kozák. São Paulo, 07. jan. 1969. 2 f. Museu Paranaense/SEEC-PR. Original em inglês.

Carta para Vladimir Kozák. São Paulo, 17 jun. 1969. 2 f. Museu Paranaense/SEEC-Pr. Original em inglês.

. Carta para Vladimir Kozák. São Paulo, 09 jan. 1971. 1 f. Museu Paranaense/SEEC-PR. Original em inglês.

Carta para Vladimir Kozák. Amparo, 06 out. 1971. 2 f. Museu Paranaense/SEEC-Pr. Original em inglês.

Carta para Vladimir Kozák. São Paulo, 14 dez. 1971. 2 f. Museu Paranaense/SEEC-PR. Original em inglês.

. Carta para Vladimir Kozák. São Paulo, 16 dez. 1974. 1 f. Museu Paranaense/SEEC-PR. Original em inglês.

Carta para Vladimir Kozák. São Paulo, 07. mar. 1975. 2 f. Museu Paranaense/SEEC-PR. Original em inglês. 


\title{
VLADIMIR KOZÁK: FRIENDSHIPS OF THE LONE WOLF
}

\begin{abstract}
Vladimir Kozák is a Czech immigrant who came to Brazil in 1924. He is a meaningful name for all brazilian indians researchers. However, his career as a researcher is virtually unknown and little is known about his personal life, his friendships and interests. Name him as an engineer, photographer, filmmaker, artist or even ethnologist is rather vague as he was a multifaceted figure who has always been involved in several activities simultaneously. This research is based on the study of his personal archive, with emphasis on epistolary documentation. Analyzed the epistolary practice of Vladimir Kozák seeking to interpret the friendship networks and the feelings that united these people. Friendship is seen as a human relationship capable of breaking distances and expand horizons, consolidating one free conversational space and cultural and personal exchange. We observed the cards as intimate form of communication that allow exposure of ideas and experience exchange between the correspondents and friends, which suggests friendly relations as ways of feeling and acting that bring men and women.
\end{abstract}

Keywords: Vladimir Kozák. Friendship. Immigrant Letters. Feetings. 